УДК 81'42

ББК 81

DOI: https://doi.org/10.17308/lic.2020.2/2855

\title{
STUDIA ROSSICA GEDANENSIA - НАУЧНЫЙ ЕЖЕГОДНИК ГДАНЬСКОГО УНИВЕРСИТЕТА
}

(Рец. на кн.: Studia Rossica Gedanensia / Rocznik. № 6. Redakcja : Zbigniew Kaźmierczyk, Katarzyna Wojan. Gdańsk, 2019. 307 c.)

И. А. Меркулова, Д. А. Чугунов

Воронежский государственный университет

\author{
STUDIA ROSSICA GEDANENSIA - \\ THE ANNUAL JOURNAL OF GDANSK UNIVERSITY \\ (Review of Studia Rossica Gedanensia / Rocznik. № 6. Redakcja : Zbigniew Kaźmierczyk, \\ Katarzyna Wojan. Gdańsk, 2019. 307 c.)
}

\author{
I. A. Merkulova, D. A. Chugunov \\ Voronezh State University
}

Studia Rossica Gedanensia - ежегодный научный журнал, известный не только у себя на родине в Польше, но и за пределами этой страны. Он является междисциплинарным, хотя все дисциплины относятся к гуманитарной области: история, лингвистика, литературоведение, культурология, фольклор. Статьи печатаются на польском, русском и английском языках.

Номер, на который мы хотим обратить внимание, последний за 2019 г., посвящен памяти профессора Университета имени Адама Мицкевича в Познани Ежи Калишана. Он включает такие разделы, как «Языкознание», «Литературоведение», «Следственная филология», «Философия и культура», «Переводоведение», «Переводы». По традиции академических научных изданий в конце журнала располагаются разделы: «Рецензии», «Хроника», «Научные отчеты».

Объектом нашего анализа стали статьи лингвистических и литературоведческих разделов.

Открывает журнал статья белорусских исследователей Валентины Масловой и Антона Лавицкого «Синтез наук как основа для возникновения юрислингвистики». Она посвящена актуальной проблеме интегративности (полипарадигмальности) лингвистических исследований. В качестве примера интегрального подхода выделяется юрислингвистика, понимаемая как «научная отрасль, объектом изучения которой являются взаимоотношения языка, права, этики, социальной коммуникации» (с. 31). Авторы выделяют три подотрасли юрислингвистики: юридико-лингвистическая герменевтика, правовое речеведение (коммуникация в правовом дискурсе), судебная лингвистическая экспертология. Наиболее востребованным сегодня является экспертологическое направление. Авторы приходят к выводу, что «Интегративность основы современной лингвистической экспертологии воплотилась в успешном привлечении теоретических знаний и прикладных разработок, в первую очередь, методологического характера из различных гуманитарных и естественнонаучных направлений» (с. 36).

Вторая статья этого раздела написана известным специалистом в области словообразования и неологии Ларисой Викторовной Рацибурской - профессором Национального исследовательского Нижегородского государственного университета имени Н. И. Лобачевского. Она называется «Новые словообразовательные форманты в российских медиа как средство освоения современной действительности». В статье анализируются новые словообразовательные форманты (суффиксы -инг, -оид, суффиксоид -гейт, префикс мега-, префиксоиды нано-, кибер-, крипто-, евро-), используемые в медийных средствах.

(С Меркулова И. А., Чугунов Д. А., 2020 
Автор говорит о том, что анализ медийных неодериватов позволяет понять, каким именно образом в языковом сознании в ходе номинации осмысливаются новые явления современной общественной жизни, а также судить о лингвокреативных способностях языковой личности и об особенностях словотворческого процесса в целом.

Продолжением словообразовательной тематики является статья японского русиста Даики Хоригути «Аффиксация глаголов, обозначающих действия в социальных сетях». Выделено три крупнейшие платформы Facebook, Twitter, Instagram и восемь главных действий, осуществляемых в социальных сетях - like 'нажать кнопку «нравиться»', share 'поделиться', comment 'написать комментарий', post 'опубликовать что-либо', repost 'опубликовать снова', tweet 'опубликовать сообщение на платформе Twitter', retweet 'поделиться сообщением на платформе Twitter', tag 'отметить, упомянуть', от которых образованы производные глаголы. Автор приходит к выводу, что за счет аффиксации актуализируется пространственно-временное восприятие действия в социальных сетях, при этом наиболее характерным является моментальность и точечность действия. К тому же префиксация способствует вторичной имперфективации глаголов.

Следующий раздел называется непривычно для русского читателя «Следственная филология». Он представлен статьей Гжегоша Ойцевича (Grzegorz Ojcewicz) «Из следственной филологии. Русские писатели в архиве Василия Митрохина (Z filologii śledczej. Pisarze rosyjscy w archiwum Wasilija Mitrochina)», написанной на польском языке. В статье рассматривается вопрос о появлении имен известных советских писателей в архивах Василия Митрохина, который, являясь сотрудником архивного отдела Первого Главного управления КГБ СССР в период с 1956 по 1984 г., накопил, а затем передал британским спецслужбам, изменив Родине и сбежав в Англию, выписки из тысяч секретных документов КГБ. Первая часть статьи посвящена биографии Василия Митрохина, вторая - архивным материалам, касающимся В. Буковского, М. Булгакова, Ю. Даниэля, А. Синявского, В. Максимова, Б. Пастернака, А. Солженицына, А. Толстого и др. Анализ документов в статье далек от филологического, а больше напоминает аналитический анализ спецслужб, направленный на дискредитацию противника. Эта статья посвящена анализу редкой, если не сказать «экзотичной», разновидности текстов официально-делового стиля русского языка, а именно - оперативных документов Отдела КГБ, работавшего с советскими писателями и поэтами с 1956 по 1984 г. Поэтому вряд ли целесообразно внутри функциональной стилистики выделять особый раздел для узкого круга официально-де- ловых документов и называть его - ни много, ни мало - особой разновидностью филологии: «Следственной филологией».

Обширным и содержательным является раздел «Литературоведение».

Открывает его статья белорусской исследовательницы Натальи Баханович «Человек и религия в прозе малых жанров рубежа XIX-XX веков». Осмысляя религиозную самоидентификацию личности в белорусской и польской прозе указанного периода, автор связывает религиозную идентичность с этнической (национальной). Компаративистский аспект размышлений позволяет здесь выявить не только «общие, созвучные времени тенденции» в развитии литературного процесса, но и весьма специфические моменты, обусловленные влиянием на мировоззрение тех или иных авторов католицизма и православия.

В статье Магдалены Домбровской «В прозе ему нет равных... “Деревня” Николая Карамзина в “Виленском еженедельнике”» (,,W prozie nie ma on sobie równego..." Wieś Nikołaja Karamzina w „Tygodniku Wileńskim" (1820 r.)) история переводов произведений Карамзина на польский язык в начале XX в. В поле зрения исследовательницы попадают такие известные вещи русского автора, как «Письма русского путешественника», «Бедная Лиза» и др. Ключевым в статье становится рассмотрение роли выпусков «Виленского еженедельника» в ознакомлении польских читателей с Карамзиным.

Продолжает тему межнациональных контактов работа Петра Глушковского «Восприятие литературного творчества Максима Горького в Польше» ("Recepcja twórczości literackiej Maksyma Gorkiego w Polsce"). Анализ охватывает большой временной период - с 1900 по 2018 г. При этом Глушковский пытается объективно осветить неоднозначную рецепцию как произведений, так и самой личности писателя. Обращая внимание на заметную политизированность самого вопроса, автор статьи подчеркивает, что большинство исследователей по сей день предпочитают избегать обобщающих формулировок, ограничиваясь погружением в какую-либо одну выбранную проблему.

Статья Марии Михновец «Кавказ в системе геополитических представлений Ф. М. Достоевского» написана в русле широкой и давно известной темы «русская литература и Кавказ». Размышления автора затрагивают при этом в первую очередь вопросы мировоззрения Достоевского, характеристики геополитической картины мира в его сознании. К сожалению, многие формулировки в статье являются словно бы отражением негативных ленинских тезисов о великорусском шовинизме или же постулатов современной западной мысли о постколониализме и страшной имперской сущности России (на это указывает, 
например, неуместное использование Михновец термина «фронтир» или приписывание Достоевскому «имперского, колонизаторского сознания»).

Статья Инессы Морозовой «Н. А. Бердяев о личности и творчестве К. Н. Леонтьева» представляет попытку вписать зарождение и распространение определенных философских, эстетических, религиозных взглядов в контекст русской общественной жизни второй половины XIX в. Основная цель подробного анализа обращений одного философа к работам другого заключается в стремлении показать огромную недооценку воззрений Леонтьева, а также их футуристически значимую оригинальность и важность для русской общественной мысли.

В статье «Поэтика жеста в повести Ф. М. Достоевского “Кроткая”» Ксения Отева исследует значимость невербального поведения персонажей повести. В центре внимания находится «семантика ключевых кинетических комплексов», что позволяет связать определенную жестикуляцию и определенные телодвижения с теми или иными внутренними побуждениями героев Достоевского, а в конечном итоге - вскрыть экзистенциальную трагедию их несостоявшегося диалога.

Статья варшавского литературоведа Сярхея Падсасонного «В круге эротизма Ф. М. Достоевского: мифы и факты» посвящена погружению в «темную» область творческой биографии русского классика. Продолжая и обобщая известные размышления над темой «ставрогинского греха» в творчестве Достоевского, исследователь избирает для себя весьма достойную позицию непредвзятого наблюдателя, который осознает «необходимость четко разграничивать достоверные факты и мифы, которые являются лишь следствием интерпретаций и домыслов».

Георгий Прохоров в статье «Европа в русской консервативной публицистике XIX века: Карамзин - Достоевский - Данилевский» оценивает размышления консервативного крыла русской общественной мысли над проблемами русско-европейских отношений. Для этого автор обращается к трем ярким образам Европы, сложившимся в художественном творчестве и публицистике известнейших русских авторов. В конце статьи отмечается парадоксальность русского консерватизма как такового.

Уже XX в. посвящена статья Максима Федорова «Демьян Бедный у истоков советского сатирического и агитационного театра». На основе архивных материалов автор воссоздает историю создания неизвестной ранее пьесы Демьяна Бедного «Вытянем!», вписывая ее в недолгую историю ранних сатирических театров послереволюционной России.

В продолжение лингвистической тематики выступают последующие статьи, связанные с теорией и практикой перевода.

Статья Л. В. Кушниной «О метаязыке перевода» отражает авторскую концепцию переводческого пространства, представляющую собой форму бытия межъязыкового и межкультурного взаимодействия коммуникантов, принадлежащих различным лингвокультурам. Целью является освещение ключевых категорий концепции переводческого пространства: смысл и его моделирование, гармония и дисгармония как критерии оценки качества перевода, синергия смыслов как условие достижения гармоничности. В качестве методологии исследования использован синергетический подход к переводу, предполагающий приращение новых смыслов, удовлетворяющих принимающей культуре (с. 235). Основные положения иллюстрируются переводами с французского и итальянского языков на русский и английский.

В следующем разделе опубликован перевод фрагмента из книги писательницы и богослова русского Зарубежья Надежды Даниловны Городецкой «Уничиженный Христос в современной русской мысли», которая ранее не переводилась на русский язык. Перевод выполнен Татьяной Сидоровой. Как отмечает переводчица, работу часто переводят как «Униженный Христос...», руководствуясь дословным переводом: humilation - с англ. 'унижение', humility - 'смирение, покорность, повиновение'. Сама Автор настаивала на переводе «уничижение» как синонимичного богословскому понятию кенозиса - самоистощания (self-emptying) Христа. По мнению ее биографа и коллеги Э. Хилл, возможно, недостаток опыта владения английским привел Городецкую к отождествлению «смирения» и «унижения» - с использованием слова humilation (c. 245). По мнению Т. П. Сидоровой, наиболее уместным для перевода является термин «самоумаление» как характерная черта христианина - независимо от его рода деятельности/служения - в стремлении подражать Христу в Его подвиге самоотречения, жертвенности, послушания.

В заключение нашего обзора заметим, что журнал Studia Rossica Gedanensia очень скупо представлен в научной электронной библиотеке elibrary.ru, а пройдя по ссылке на сайт журнала, обнаруживаешь, что он давно не обновлялся и познакомиться со свежим номером невозможно. 
Воронежский государственный университет

Меркулова И. А., доктор филологических наук, доиент кафедры теоретической и прикладной лингвистики

\section{E-mail:igel1@yandex.ru}

Чугунов Д. А., доктор филологических наук, профессор кафедры истории и типологии русской и зарубежной литературь

E-mail:dmtrchugunov@yandex.ru

Поступила в редакциию 20 февраля 2020 г.

Принята к публикации 25 марта 2020 г.

\section{Для цитирования:}

Меркулова И. А., Чугунов Д. А. Studia Rossica Gedanensia - научный ежегодник Гданьского университета (Рец. на кн.: Studia Rossica Gedanensia / Rocznik. № 6. Redakcja : Zbigniew Kaźmierczyk, Katarzyna Wojan. Gdańsk, 2019. 307 c.) // Вестник Воронежского государственного университета. Серия: Лингвистика и межкультурная коммуникация. 2020. № 2. C. 156-159. DOI: https://doi.org/10.17308/lic.2020.2/2855
Voronezh State University

Merkulova I. A., Doctor of Philology, Associate Professor of the Theoretical and Applied Linguistics Department E-mail:igel1@yandex.ru

Chugunov D. A., Doctor of Philology, Professor of the History and Typology of Russian and Foreign Literature Department

E-mail:dmtrchugunov@yandex.ru

Received: 20 February 2020

Accepted: 25 March 2020

\section{For citation:}

Merkulova I. A., Chugunov D. A. Studia Rossica Gedanensia - the Annual Journal of Gdansk University (Review of: Studia Rossica Gedanensia / Rocznik. № 6. Redakcja : Zbigniew Kaźmierczyk, Katarzyna Wojan. Gdańsk, 2019. 307 c.) Proceedings of Voronezh State University. Series: Linguistics and Intercultural Communication. 2020. No. 2. Pp. 156-159. DOI: https://doi.org/10.17308/lic.2020.2/2855 